\title{
Identification of in vivo HSP90-interacting proteins reveals modularity of HSP90 complexes is dependent on the environment in psychrophilic bacteria
}

\author{
Laura García-Descalzo • Alberto Alcazar • \\ Fernando Baquero • Cristina Cid
}

Received: 4 May 2010 /Revised: 15 September 2010 /Accepted: 16 September 2010 /Published online: 2 October 2010

(C) The Author(s) 2010. This article is published with open access at Springerlink.com

\begin{abstract}
Heat shock protein 90 (HSP90) is a conserved molecular chaperone that functions as part of complexes in which different client proteins target it to diverse sets of substrates. In this paper, HSP90 complexes were investigated in $\gamma$-proteobacteria from mild (Shewanella oneidensis) and cold environments (Shewanella frigidimarina and Psychrobacter frigidicola), to determine changes in HSP90 interactions with client proteins in response to the adaptation to cold environments. HSP90 participation in cold adaptation was determined using the specific inhibitor 17allylamino-geldanamycin. Then, HSP90 was immunoprecipitated from bacterial cultures, and the proteins in HSP90 complexes were analyzed by two-dimensional gel electrophoresis and identified by matrix-assisted laser desorption/ ionization time-of-flight mass spectrometry. According to HSP90-associated protein analysis, only 15 common proteins were found in both species from the same genus, $S$. oneidensis and $S$. frigidimarina, whereas a significant higher number of common proteins were found in both psychrophilic species $S$. frigidimarina and P. frigidicola 21 $(p<0.001)$. Only two HSP90-interacting proteins, the chaperone proteins DnaK and GroEL, were common to the three species. Interestingly, some proteins related to
\end{abstract}

L. García-Descalzo • F. Baquero • C. Cid $(\bowtie)$

Centro de Astrobiologia (CSIC-INTA),

Ctra. Ajalvir, km 4, Torrejón de Ardoz,

28850 Madrid, Spain

e-mail: cidsc@inta.es

\author{
A. Alcazar \\ Department of Investigation, Hospital Ramon y Cajal, \\ 28034 Madrid, Spain \\ F. Baquero \\ Department of Microbiology, Hospital Ramon y Cajal, \\ 28034 Madrid, Spain
}

energy metabolism (isocitrate lyase, succinyl-CoA synthetase, alcohol dehydrogenase, $\mathrm{NAD}(+)$ synthase, and malate dehydrogenase) and some translation factors only interacted with HSP90 in psychrophilic bacteria. We can conclude that HSP90 and HSP90-associated proteins might take part in the mechanism of adaptation to cold environments, and interestingly, organisms living in similar environments conserve similar potential HSP90 interactors in opposition to phylogenetically closely related organisms of the same genus but from different environments.

Keywords Protein interactions - Cold adaptation · Heat shock protein $90 \cdot \mathrm{HSP} 90 \cdot$ High temperature protein G . HTPG · Psychrophiles · Extremophiles
Abbreviations
HSP90
Heat shock protein 90
HTPG
High temperature protein $\mathrm{G}$
$17 \mathrm{AGG}$ 17-Allylamino-17-demethoxy-geldanamycin
2-DGE Two-dimensional gel electrophoresis
MALDI-TOF Matrix-assisted laser desorption/ionization $\mathrm{MS}$ time-of-flight mass spectrometry

\section{Introduction}

Molecular chaperones are essential components of the quality control machinery present in the cell (Hartl and Hayer-Hartl 2002). They optimize bacterial physiological responses, directing client proteins, facilitating developmental signaling, and, as heat shock proteins (HSPs), are indispensable for survival in unpredictable environments. HSPs have been identified and characterized from various Bacteria and Archaea, and, like most organisms, they 
generally possess more than one set of HSPs (Laksanalamai and Robb 2004). Many microorganisms from extreme environments have been well characterized, and increasing access to genomic sequence data has recently allowed the analysis of the protein families related to stress responses. According to these data, HSPs appear to be ubiquitous in extremophiles (Laksanalamai and Robb 2004).

Environmentally sensitive chaperone functions would have different potential consequences for the evolution of populations and lineages under selection in changing environments (Rutherford 2003). In this work, we propose that such changes might influence the common adaptation pattern of different microbial species to a particular environment, leading to positive covariation and explaining the long-term stability of population and community abundance in the absence of compensatory dynamics or competition.

Among HSPs, HSP90 is a key component of this machinery. It is a ubiquitous molecular chaperone that is found in Eubacteria and all branches of Eukarya (Zhao et al. 2005) and have been found in a variety of organisms suggesting that it is ancient and conserved (Chen et al. 2006). HSP90 typically functions as a part of large complexes, which include other client proteins essential in posttranslational control (Chen et al. 2006). It is thought that HSP90 target to its client proteins to different sets of substrates (Zuehlke and Johnson 2009). The prokaryote HSP90 homolog, also known as high temperature protein G (HTPG), exists in most bacterial species, and it has evolved into three lineages via two gene duplication events. Hsp $90 /$ $h t p G$ genes, like most bacterial genes, have only one exon. Their proteins are 588-681 amino acids long. This subfamily of proteins is the shortest in the HSP90 family, with a molecular mass ranging from 66.7 to $78.0 \mathrm{kDa}$ (Chen et al. 2006). HSP90 implication in temperature adaptation seems to be a controversial subject. Although $h t p G$ gene is not completely essential neither in Escherichia coli nor in Bacillus subtilis (Bardwell and Craig 1988; Versteeg et al. 1999), it has been found to be abundant in normal growth conditions. In both cases, the $h t p G$ deletion mutant is viable but grows poorly at high temperatures. In the absence of HSP90, recovery of cells from a heat shock is retarded, and this delay can be eliminated by overproduction of HSP90 (Versteeg et al. 1999). In B. subtilis, $h t p G$ gene is induced about 10 -fold upon a sudden temperature increase at the level of both transcription and translation (Versteeg et al. 2003). Regarding cold acclimation, very few bacterial species have been studied until now, but it is known that HSP90 is essential for thermal stress management in cyanobacteria (Tanaka and Nakamoto 1999) and contributes significantly to the ability of cyanobacteria to acclimate to cold temperatures (Hossain and Nakamoto 2002).
The HSP90 because of its interaction with essential proteins, its ubiquity, and its high degree of conservation provides an interesting tool for adaptation and evolution studies. With the aim of determining whether HSP90 and its interacting proteins take part in the mechanism of adaptation to cold environments, we compared HSP90associated proteins in two species from distant bacterial genera (Shewanella frigidimarina and Psychrobacter frigidicola) from a similar Antarctic cold environment and in two bacterial species of the same genus (Shewanella oneidensis and S. frigidimarina) and from different environments (mesophilic and psychrophilic bacteria, respectively).

gamma-Proteobacteria represent a collection of microorganisms that form a taxonomic group based on $16 \mathrm{~S}$ rRNA comparisons, but they are diverse in their habitats, lifestyles, and metabolic preferences (Mrázek et al. 2006). In this group, the genus Shewanella comprises more than 20 species inhabiting a wide range of environments including spoiled food (Jorgensen and Huss 1989; Shewan 1971), oil field wastes (Deppe et al. 2005), redox interfaces in marine and freshwater, cold water, and sediments of the deep sea and mesophilic ones all around the planet. $S$. oneidensis has been the most studied species in the genus as it is unique among known bacteria in its capacity to use a wide range of terminal electron acceptors in respiration including heavy metals, which makes it an attractive candidate for bioremediation (Heidelberg et al. 2002; Lovley et al. 2004). Several Shewanella species have been found in Antarctic Continental shelf sediments (Bozal et al. 2002; Brinkmeyer et al. 2003) as well as in sea-ice microbial communities (adapted to grow at temperatures below $4^{\circ} \mathrm{C}$ ). Some of these are cultivated strains, while others are as yet uncultivated and exemplify psychrophilic Antarctic strains identified only by sequence analysis of 16S rRNA. Among them, as counterparts of the mesophilic bacterium $S$. oneidensis, a psychrophilic species from this genus has been considered in this study: S. frigidimarina, a bacterial species that was originally isolated from the Antarctic coastal sites (Bowman et al. 1997, 2003).

Further, the genus Psychrobacter includes species that were primarily isolated from cold to warm, slightly to highly saline ecosystems ranging from glacial ice to sea-ice to chilled meat and fish to clinical samples. Among these bacteria, we have compared a bacterial species: P. frigidicola, isolated from the same Antarctic cold environment (Bowman et al. 1996).

Due to the potential importance of HSP90 and its client proteins, this paper has focused on HSP90-associated proteins from the mesophilic bacterium $S$. oneidensis and from the psychrophilic bacteria $S$. frigidimarina and P. frigidicola in order to elucidate the changes of HSP90-interacting network in dependence of environment. Firstly, the participation of HSP90 in cold acclimation was studied in cultures of $S$. 
oneidensis and S. frigidimarina using the specific HSP90 inhibitor 17-allylamino-17-demethoxy-geldanamycin (17AGG; Prodromou et al. 1997; Stebbins et al. 1997). Secondly, HSP90 was immunoprecipitated from bacterial cultures of $S$. oneidensis, $S$. frigidimarina, and $P$. frigidicola with a specific anti-HSP90 antibody. HSP90 immunoprecipitates were subjected to two-dimensional gel electrophoresis (2-DGE). Finally, proteins were identified from individual gels by peptide mass fingerprinting using matrix-assisted laser desorption/ionization time-of-flight (MALDI-TOF) mass spectrometry (MS).

\section{Materials and methods}

Bacterial strains and growth conditions Microorganisms included in this study were purchased from culture collections (ATCC ${ }^{\circledR}$ ). Broth cultures of $S$. oneidensis (MR-1, 700550 ${ }^{\mathrm{TM}}$ ), S. frigidimarina (ACAM591, $700753^{\mathrm{TM}}$ ), P. frigidicola (ACAM304, 700361 1 TM), E. coli (DH5a, 53868 ${ }^{\mathrm{TM}}$ ), B. subtilis (NCIB3610, 6051 ${ }^{\mathrm{TM}}$ ), Salmonella bongori (CIP82.33, 43975 ${ }^{\mathrm{TM}}$ ), and Burkholderia fungorum (CCUG31961T, BAA463 ${ }^{\mathrm{TM}}$ ) were prepared as follows: $500-\mu \mathrm{l}$ aliquots of mid-exponential grown cultures were transferred to 500-ml Erlenmeyer flasks containing $100 \mathrm{ml}$ fresh, temperature-equilibrated medium (Marine broth 2216 for psychrophilic species and Luria-Bertani for mesophilic species). Four biological replicates were grown from each bacterial species. The flasks were incubated aerobically with agitation at $150 \mathrm{rpm}$, at $12^{\circ} \mathrm{C}$ or $30^{\circ} \mathrm{C}$ for psychrophilic or mesophilic bacteria, respectively, until an absorbance $\left(\mathrm{OD}_{600}\right)$ of 0.3 had been attained. The cells were then harvested by centrifugation $(10,000 \times g, 15 \mathrm{~min}$, $4^{\circ} \mathrm{C}$ ), rinsed in PBS, and stored at $-20^{\circ} \mathrm{C}$ until use. Cultures of $S$. oneidensis and $S$. frigidimarina for viability assays were prepared in multiwell plates with their corresponding culture conditions.

All general chemicals were purchased from Sigma unless stated otherwise in parenthesis. The chemicals used in isoelectric focusing (IEF) and in sodium dodecyl sulfatepolyacrylamide gel electrophoresis (SDS-PAGE) were purchased from GE Healthcare.

MTT assay A colorimetric assay based on 3-(4, 5dimethylthiazol-2-yl)-2, 5-diphenyl tetrazolium bromide (MTT) was used for detection of bacterial viability in the presence of 17AGG. MTT is a yellow tetrazolium salt that is converted into blue formazan by dehydrogenases of live cells. The amount of blue formazan formation is proportional to the number of live bacteria in the sample, so the MTT assay can be used satisfactorily to quantify the viability of the bacteria within appropriate cell concentrations (Abate et al. 2004). The assay was performed by incubating bacterial cultures of $10^{5}$ bacteria $/ \mathrm{ml}$ in the presence of 17AGG $10 \mu \mathrm{M}$ for $24 \mathrm{~h}$ and then with $0.2 \mathrm{mg} /$ $\mathrm{ml}$ sterile MTT during $1.5 \mathrm{~h}$ in an incubator at $12^{\circ} \mathrm{C}$ or $30^{\circ} \mathrm{C}$. After the incubation period, bacteria were lysed with an equal volume of $10 \mathrm{mM} \mathrm{HCl}, 10 \%$ SDS in the incubator overnight. Values are given in absorbances (test $595 \mathrm{~nm}$, reference $690 \mathrm{~nm}$ ).

Amino acid sequence alignment of HSP90 and comparative phylogenetic analysis of bacterial species The multiple protein alignments of HSP90/HTPG sequences were carried out using the ClustalW program. The HSP90 phylogenetic tree was established from 15 sequence alignments using neighbor-joining and parsimonia methods. The tree was drawn using the MEGA program (Tamura et al. 2007).

Preparation of cell extracts and protein determination Bacteria from each biological replicate (four in total) were obtained from the individual cultures. The cells were harvested, washed, and lysed in buffer A $(20 \mathrm{mM}$ Tris$\mathrm{HCl}, \mathrm{pH} 7.6 ; 140 \mathrm{mM}$ potassium chloride; $2 \mathrm{mM}$ benzamidine; $1 \mathrm{mM}$ EDTA; $10 \mu \mathrm{g} / \mathrm{ml}$ pepstatin A, leupeptin, and antipain), using a French Press at $4^{\circ} \mathrm{C}$. Cell debris was removed by centrifugation at $11,000 \times g$ for $10 \mathrm{~min}$ to obtain a supernatant, and the protein extracts were processed using a 2-D Clean-Up kit (GE Healthcare, Spain). The pellet was frozen and stored at $-80^{\circ} \mathrm{C}$. The protein content was determined in cell extracts using the Bio-Rad protein assay based on the Bradford method using different dilutions of BSA as the standard. The samples were adjusted to a protein concentration of $5-10 \mathrm{mg} / \mathrm{ml}$. All steps were carried out at $4^{\circ} \mathrm{C}$.

Immunoprecipitation of HSP90 Cell extracts were immunoprecipitated with the monoclonal anti-HSP90 antibody (clone AC88, Calbiochem, San Diego, CA, USA) in order to study the HSP90-associated proteins, as previously described (Cid et al. 2004, 2007a), with some modifications. Firstly, HSP90 was immunoprecipitated in each sample $(100 \mu \mathrm{g})$ with $1 \mu \mathrm{g}$ of antibody for $4 \mathrm{~h}$ at $4^{\circ} \mathrm{C}$ in buffer A. Protein G-Sepharose ( $25 \mu \mathrm{l}$ of $50 \%$ slurry) was then added for $1 \mathrm{~h}$ at $4^{\circ} \mathrm{C}$ and centrifuged. The immunoprecipitation was developed in stringent conditions to minimize unspecific complexes. The immunoprecipitates were washed in $1 \mathrm{ml}$ of cold buffer with $0.5 \mathrm{M}$ lithium chloride, then washed two times in $1 \mathrm{~mL}$ of cold buffer without lithium chloride, and subjected to SDS-PAGE followed by silver staining or immunoblotting. Further, immunoprecipitations were carried out for 2-DGE followed by protein identification MALDI-TOF MS peptide mass fingerprinting. HSP90 was immunoprecipitated from each sample $(1,200 \mu \mathrm{g})$ with $4 \mu \mathrm{g}$ of the antibody and $100 \mu \mathrm{l}$ of 
protein G-Sepharose as described above. In all experiments, negative controls omitting the antibody were run in parallel.

Western blot Western blotting was used to detect HSP90 in the cell extracts. Cell extracts $(100 \mu \mathrm{g}$ of protein) were subjected to immunoprecipitation with the monoclonal antiHSP90 antibody and followed by SDS-PAGE using 5-12\% discontinuous acrylamide $(2.6 \% \mathrm{C})$ gels. The gels were electroblotted onto polyvinylidene difluoride membranes (GE Healthcare) which were individually incubated for $1 \mathrm{~h}$ with monoclonal anti-HSP90 antibody, washed and then incubated after at room temperature for $1 \mathrm{~h}$ with peroxidase-conjugated goat anti-species $\operatorname{IgG}$ antibody (Bio-Rad, USA), developed with ECL reagent (GE Healthcare, Spain), and exposed to film (Hyperfilm, GE Healthcare, Spain).

Two-dimensional gel electrophoresis Horizontal slab gel IEF was combined with SDS-PAGE for 2-DGE by using the Multiphor II apparatus for the first dimension and standard vertical slab gel electrophoresis for the second dimension, according to the manufacturer's instructions. Immunoprecipitated samples were prepared in $7 \mathrm{M}$ urea/2 $\mathrm{M}$ thiourea and 5\% $\beta$-mercaptoethanol, centrifuged and applied to $\mathrm{pH}$ gradient strips for IEF. Carrier ampholyte urea IEF was carried out using immobilized $\mathrm{pH} \mathrm{3-10} \mathrm{and} \mathrm{3-11} \mathrm{non-linear} \mathrm{gradient}$ strips (18 and $24 \mathrm{~cm}$, respectively).

After the first dimension, the IEF strips were processed for the second dimension in SDS-PAGE carried out on $12 \%$ acrylamide (2.6\% crosslinking) gels $(1.0 \mathrm{~mm}$ thick) with IEF strips being used as the stacking gels. The spots resolved by 2-DGE from the preparative gels were stained with Coomassie blue or with MALDI-MS compatible silver reagent for peptide mass fingerprinting analysis and protein identification.

Protein identification by peptide mass fingerprinting Protein spots were excised manually from the Coomassie or silver-stained 2-DGE gels, de-stained, and then digested automatically using a Proteineer DP protein digestion station (Bruker-Daltonics, Bremen, Germany). The identification protocol used was based on the method previously described in (Cid et al. 2007b) with minor variations. An aliquot of the above digestion solution was mixed with an aliquot of $\alpha$-cyano-4-hydroxycinnamic acid (Bruker-Daltonics) in 33\% aqueous acetonitrile and $0.1 \%$ trifluoroacetic acid. This mixture was deposited onto a MALDI probe $(600 \mu \mathrm{m}$ AnchorChip for BrukerDaltonics) and allowed to dry at room temperature. MALDI-TOF MS (/MS) data were obtained using an Ultraflex TOF-TOF mass spectrometer equipped with a LIFT-MS/MS device (Bruker-Daltonics) and a 4,800 MALDI-TOF-TOF mass spectrometer (Applied Biosys- tems). Spectra were acquired in the positive-ion mode at $50 \mathrm{~Hz}$ laser frequency, and 100 to 1,500 individual spectra were averaged. When available, for fragment ion analysis in the tandem time-of-flight (TOF/TOF) mode, precursors were accelerated to $8 \mathrm{kV}$ and selected in a timed ion gate. Spectral data were analyzed through MS BioTools program (Bruker-Daltonics) or ProteinPilot software (Applied Biosystems) to search the NCBInr database using the Mascot database search algorithm (Matrix Science, London, UK; Cid et al. 2010).

\section{Results}

HSP90 inhibition reduces the bacterial viability at cold temperature With the aim of determining whether HSP90 and its client proteins take part in the mechanism of adaptation to cold environments, we studied the viability of $S$. oneidensis and S. frigidimarina in the presence of the specific HSP90 inhibitor $17 \mathrm{AGG}$ at $12^{\circ} \mathrm{C}$ and $30^{\circ} \mathrm{C}$. The doses of $17 \mathrm{AGG}$ used in the present study were previously determined by a set of dose-response experiments in which the effects of 17AGG were examined using cultures of $S$. oneidensis (Fig. 1a). Since the calculated IC50 was $7.7 \mu \mathrm{M}$, a dose of $10 \mu \mathrm{M}$ was chosen for further experiments. Then, the viability of $S$. oneidensis and $S$. frigidimarina in the presence of 17AGG was evaluated with a MTT colorimetric assay. Decreased MTT activity is considered to be an index of bacterial damage. As a linear relationship between MTT OD values and concentration of bacteria was found at cell concentrations ranging from $10^{4}$ to $10^{6}$ bacteria/ml (data not shown), the assay of living metabolically active bacteria was performed by incubating cultures of $10^{5}$ bacteria $/ \mathrm{ml}$ with MTT. 17AGG very significantly induced lower MTT activity values on both Shewanella species as compared with their corresponding control cultures. In S. oneidensis, a significant difference can be found in MTT activity values between cultures treated with $17 \mathrm{AGG}$ and control at $12^{\circ} \mathrm{C}$ or $30^{\circ} \mathrm{C}$ $(p<0.01$; Fig. 1b), and similar significance was obtained for S. frigidimarina at $30^{\circ} \mathrm{C}$, but HSP90 inhibition was even higher for treated cultures of $S$. frigidimarina at $12^{\circ} \mathrm{C}(p<$ 0.001 ; Fig. 1c). Considering their percentages with respect to their corresponding control cultures, both Shewanella species at $30^{\circ} \mathrm{C}$ treated with $17 \mathrm{AGG}$ grew less than did their corresponding control cultures $(73 \%$ S. oneidensis $(p<0.05)$ and $71 \% \mathrm{~S}$. frigidimarina $(p<0.01))$ and very poorly at $12^{\circ} \mathrm{C}$ $(51 \%$ S. oneidensis $(p<0.05)$ and $41 \%$ S. frigidimarina $(p<$ 0.001 ); Fig. 1d). The comparison in these two bacterial species also demonstrated a significant difference in MTT values in each species at $12^{\circ} \mathrm{C}$ and $30^{\circ} \mathrm{C}(p<0.01$ for $S$. oneidensis and $p<0.001$ for $S$. frigidimarina) and between both species at $12^{\circ} \mathrm{C}(p<0.05$; Fig. $1 \mathrm{~d})$. All these experi- 
Fig. $1 S$. oneidensis and $S$. frigidimarina viability after exposure to HSP90 specific inhibitor 17AGG. a Doseresponse experiments of $17 \mathrm{AGG}$ in $S$. oneidensis cultures at $12^{\circ}$ C. Values are given in absorbances (test $595 \mathrm{~nm}$, reference $690 \mathrm{~nm}$ ). The calculated IC50 was $7.7 \mu \mathrm{M}$. 17AGG decreased MTT activity in $S$. oneidensis (b) and $S$. frigidimarina $(\mathbf{c})$ at $12^{\circ} \mathrm{C}$ and $30^{\circ} \mathrm{C}$. Data represent the mean \pm SEM of three experiments run in duplicate. Statistical differences were studied by Student's $t$ test $\left({ }^{*} p<0.05 ; * * p<0.01 ; * * * p<\right.$ 0.001 , compared to the corresponding control). d MTT activity in cultures of $S$. oneidensis and S. frigidimarina treated with 17AGG. Statistical differences were studied by onesample $t$ test $(* p<0.05 ; * * p<$ $0.01 ; * * * p<0.001)$, compared to the corresponding control as $100 \%$, and comparison between percentages were done by Student's $t$ test
A

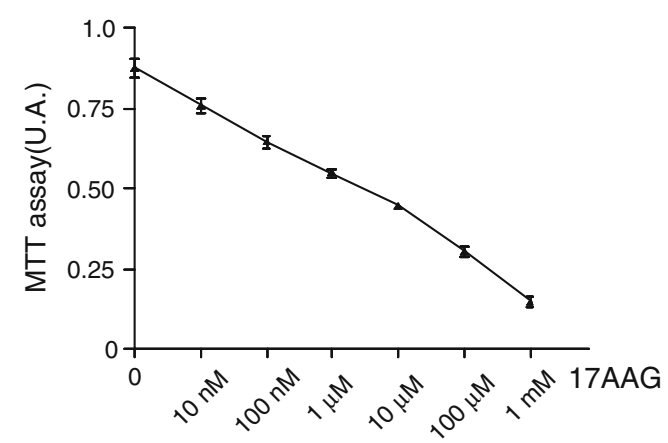

D

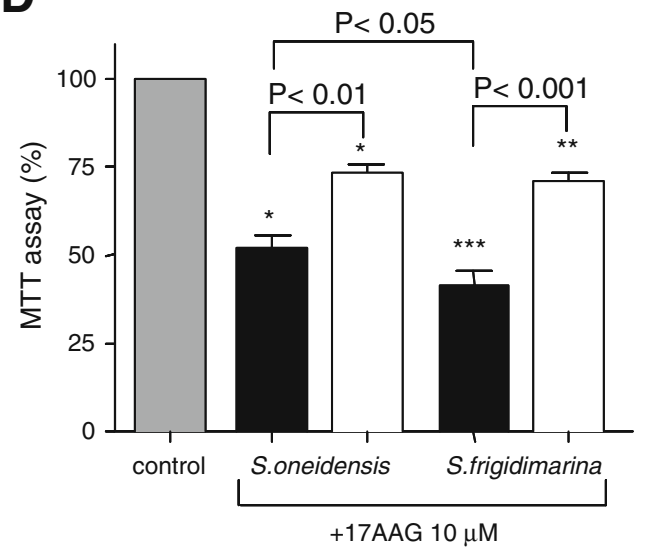

B

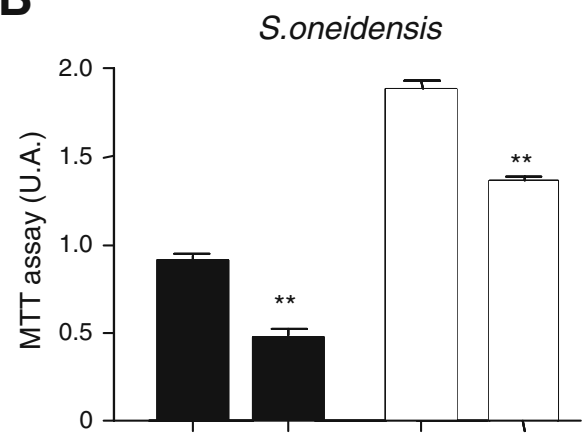

C

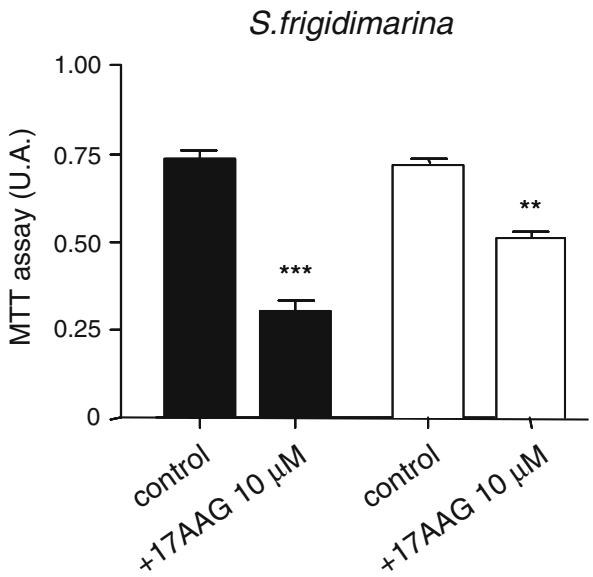

Temperature of culture

$12^{\circ} \mathrm{C} \square 30^{\circ} \mathrm{C}$

ments inhibiting HSP90 demonstrate the participation of this protein in cell viability and in cold adaptation in the psychrophilic bacteria $S$. frigidimarina.

Comparative phylogenetic analysis of HSP90 from Shewanella and Psychrobacter To establish the homology of HSP90 in the species compared, we used a final data set of 15 available sequences (12 from the genus Shewanella and three from the genus Psychrobacter) and 673 sites. HSP90 amino acid sequences were deduced from DNA sequence data from publicly available genomes by conducting a TBLASTN. HSP90 sequences were obtained from the NCBI database and UniProt Knowledgebase. The phylogenetic analysis of HSP90 for comparison of the bacteria is shown in Fig. 2. HSP90 protein comparisons showed that sequences belonging to each genus can be clearly distinguished. Further, a comparative view of the unrooted HSP90 tree shows the expected separate grouping of Shewanella and Psychrobacter (Fig. 2).

Immunoprecipitation of HSP90 The immunoprecipitation of HSP90 was achieved with monoclonal anti-HSP90

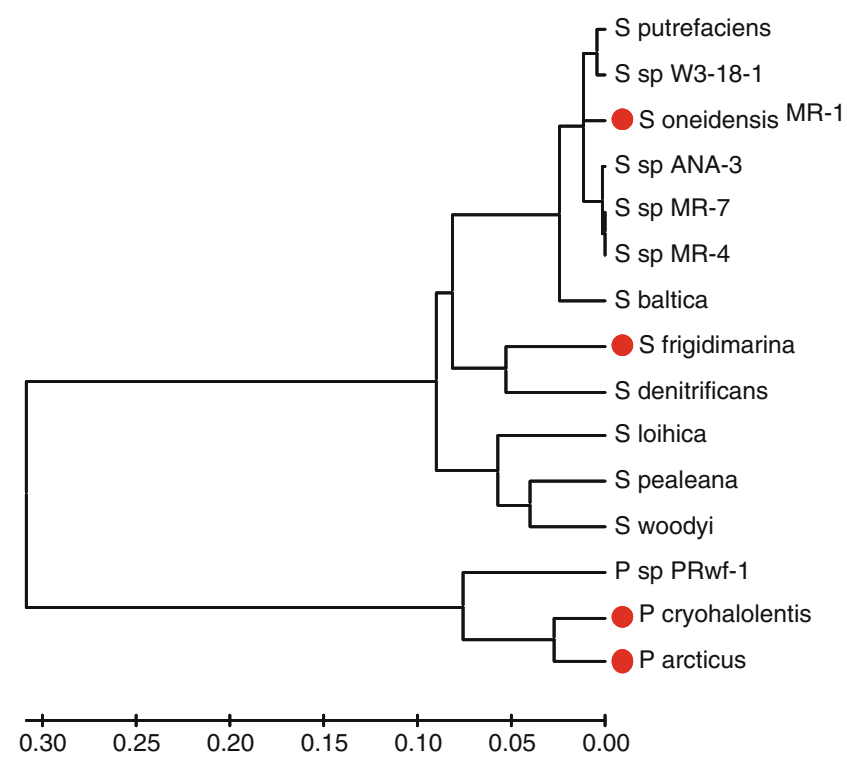

Fig. 2 Phylogenetic tree from HSP90. Phylogenetic tree derived from HSP90 sequences, using the neighbor-joining method 
antibody that was raised against a conserved epitope shown to react with HSP90 in multiple species, including the prokaryote HSP90 homolog HTPG (Lopatin et al. 2000; Riehl et al. 1985). Western blot analysis was carried out to confirm that the anti-HSP90 antibody used specifically recognizes this protein in several bacterial genera and to determine whether the antibody is able to immunoprecipitate the protein. The bacterial genera analyzed were $S$. oneidensis, S. frigidimarina, and P. frigidicola (Fig. 3). Other bacterial genera were used as controls: E. coli, B. subtilis, S. bongori, and B. fungorum (not shown). Immunoprecipitated HSP90 (Fig. 3a) was identified by Western blot analysis (Fig. 3b) and excised from silverstained SDS-PAGE and subjected to MALDI-TOF MS peptide mass fingerprinting in order to corroborate their identity. In all genera, the immunoprecipitated and blotted protein was identified as the prokaryote HSP90 homolog HSP90/HTPG. The results shown in Fig. 3 demonstrate that the antibody had immunoprecipitated the HSP90/HTPG protein in cell extracts, which was detected with an apparent molecular weight between 72 and $74 \mathrm{kDa}$.

Study of proteins in HSP90 complexes in S. oneidensis, $S$. frigidimarina, and P. frigidicola We have selected three

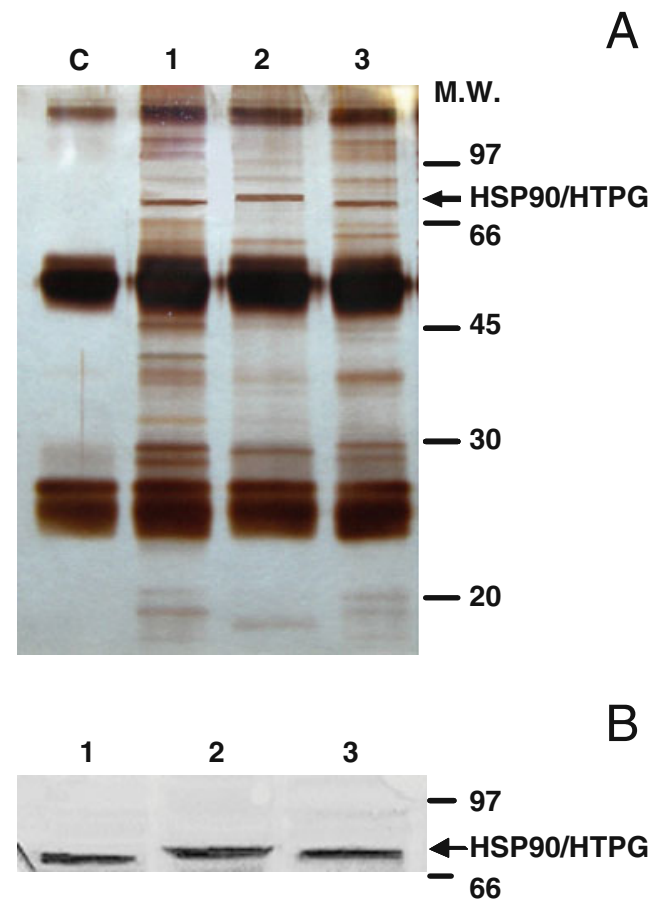

Fig. 3 Determination of antibody reaction to HSP90 using cell extracts. a Silver-stained gel of HSP90 immunoprecipitates from cell extracts of $S$. frigidimarina (1), S. oneidensis (2), and P. frigidicola (3) and a control without cell extract (c). b Western blot for HSP90 in cell extracts from the same immunoprecipitates incubated with anti-HSP90 monoclonal antibody. The positions of relative molecular weight standards (in thousands) are also indicated. Three different cultures were assayed in all experiments; the figures are representative results
HSP90 $\gamma$-proteobacteria for comparative analysis. These include $S$. oneidensis, S. frigidimarina, and P. frigidicola. In addition to these psychrophilic species, $S$. oneidensis was selected as mesophilic bacterium to compare with $S$. frigidimarina because both would share the same genetic background but are adapted to different environments. With the aim of identifying the proteins that interact with HSP90 in these compared species, immunoprecipitations of HSP90 complexes were carried out from the individual species under the conditions described above. Isolated complexes were separated on SDS-PAGE and were silver-stained. At first glance, it could be observed that the protein pattern in HSP90 immunoprecipitates was more similar in the psychrophilic species than in either of the Shewanella species (Fig. 3). Therefore, 2-DGE experiments followed by image analysis of HSP90 immunoprecipitates were developed to elucidate the number and identity of common spots in the three species in at least three out of four replicates of 2-DGE gels. The most abundant spots were then isolated from gels and identified by MALDI-TOF MS peptide mass fingerprinting. Figure 4 summarizes the methodological strategy to identify the HSP90-associated proteins in the three bacterial species compared, $S$. oneidensis, $S$. frigidimarina, and P. frigidicola.

HSP90-interacting proteins in S. oneidensis and $S$. frigidimarina The 2-DGE analysis of HSP90 immunoprecipitates in S. oneidensis and S. frigidimarina detected 132 total spots, 66 in each bacterial species (Fig. 5a, b). The most intense spots in image analysis (30 in $S$. oneidensis and 35 in $S$. frigidimarina) were identified by MALDI-TOF MS peptide mass fingerprinting (Tables 1 and 2). In $S$. frigidimarina, 15 spots (24\%) were common to $S$. oneidensis (Fig. 6). These spots were identified as chaperone proteins DnaK and GroEL; ribosomal proteins S1, S4, L1, and L5; flavocytochrome C fumarate reductase; outer membrane porin; single-strand binding protein; protein kinase; methylcitrate synthase; universal stress protein; and three hypothetical proteins. The rest of HSP90associated proteins identified by MALDI-TOF MS were not common in these species, taking into account their similarity in BLAST analysis.

HSP90-interacting proteins in S. frigidimarina and $P$. frigidicola In the 2-DGE experiments of HSP90 immunoprecipitates in $S$. frigidimarina and $P$. frigidicola, 122 total spots were detected, 66 and 56 spots, respectively (Fig. 5b, c). The most intense spots in image analysis (35 in $S$. frigidimarina and 30 in $P$. frigidicola) were identified by MALDI-TOF MS peptide mass fingerprinting (Tables 2 and 3), and 21 (34\%) of these were found in S. frigidimarina and common to P. frigidicola (Fig. 6). The common HSP90-associated proteins were identified by MALDI- 
Fig. 4 Summary of the overall experimental strategy.

Schematic representation of the experimental design followed to identify HSP90-interacting proteins in the three compared bacterial species

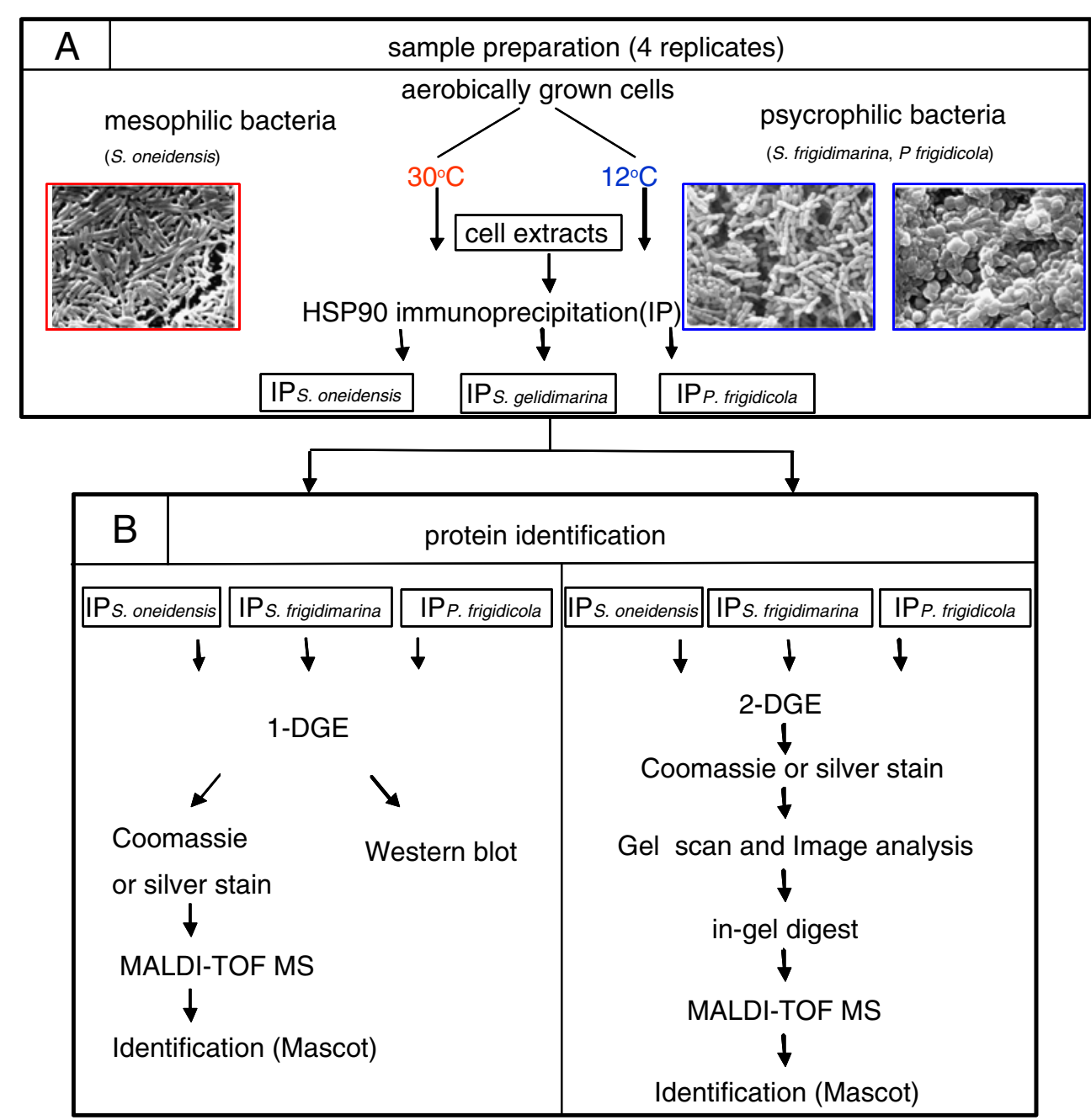

TOF MS peptide mass fingerprinting as chaperone proteins DnaK and GroEL; ribosomal proteins L3, L27, S3, and S11; translation initiation factors IF2 and IF3; Rne; RNApol; PolyA; EF-G; NADsyn; ICL; MDH; MinD; SCoA; ADH; Pcryo; TerD; and LysM. Only two of these HSP90-associated proteins (DnaK and GroEL) were found to be common to all three bacterial species. The rest of HSP90-associated proteins identified by MALDI-TOF MS were not common in these species, taking into account their similarity in BLAST analysis.

Two independent laboratories validated the identification by MALDI-TOF MS peptide mass fingerprinting to corroborate the identities of the proteins shown in Tables 1 , 2 , and 3. The score included in these tables was the lowest score registered for each protein identification. Taken together, the results described here demonstrate that a significantly $(p=0.0006)$ higher number of common HSP90-associated proteins are found in S. frigidimarina common to $P$. frigidicola compared to $S$. oneidensis (Fig. 6). The total number of common spots in S. oneidensis and S. frigidimarina was not significantly different $(p=$ 0.501 ) from that in $S$. frigidimarina and P. frigidicola.

Regarding the position of the proteins in the 2-DGE gels (Fig. 5), it has been suggested that there is a shift in the average isoelectric point of the proteome toward basic values as the optimum growth temperature changes to minimize protein aggregation with variable growth temperature. In extremophiles, most proteins appear to be acidic, with the $\mathrm{p} I$ ranging from 4 to 6 (Fig. 5 and Tables 1, 2, and 3). However, a small number of HSP90-interacting proteins appear to be very basic proteins with $\mathrm{p} I \mathrm{~s}$ of more than 8 . This suggests a possible alternative role for these proteins, as exemplified by the nucleotide binding proteins found in the HSP 15 from $E$. coli (Kawashima et al. 2000). Nevertheless, when they occur in extremophiles, basic proteins are always accompanied by at least one paralog with an acidic $\mathrm{p} I$ (Fig. 5). In this case, the greater coincidence in protein positions in 2-DGE gels in psychrophilic species as compared to both the Shewanella species (Fig. 5a, b) may be a result of the same shift in the isoelectric point due to a cold environment. In order to 

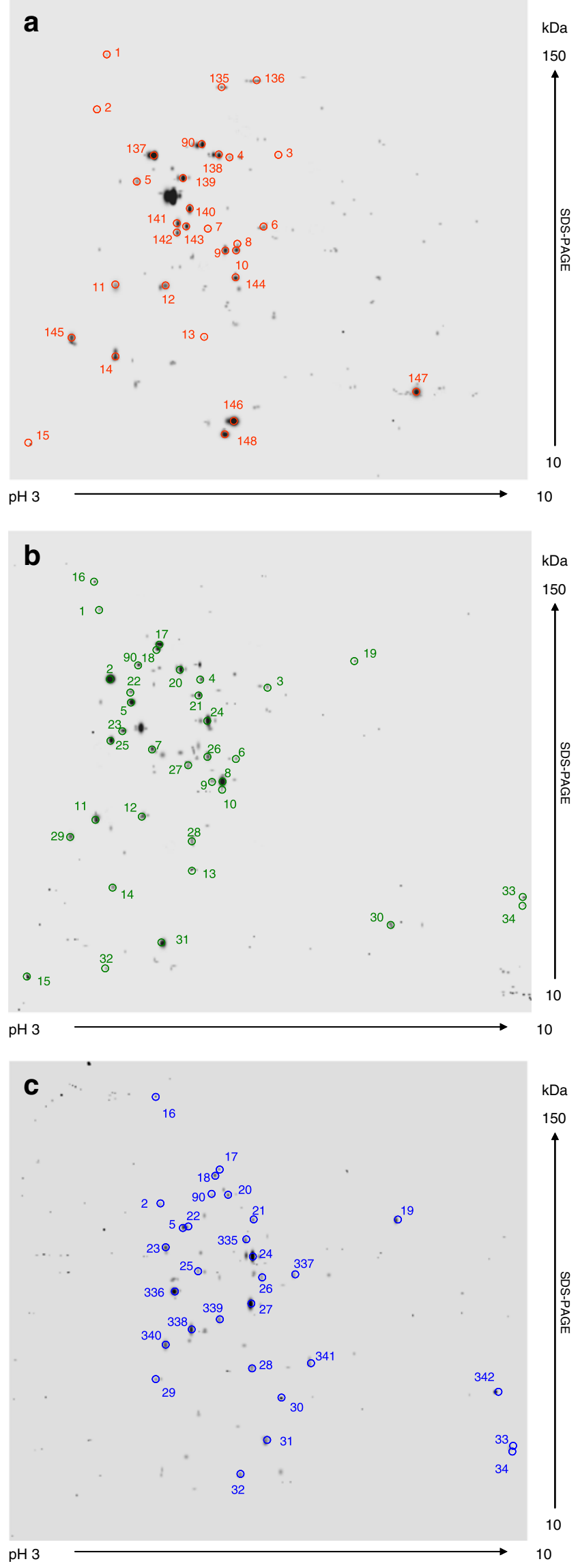

Fig. 5 2-DGE gels of HSP90-interacting proteins. Cell extracts were obtained from $S$. oneidensis, S. frigidimarina, and P. frigidicola and separately subjected to immunoprecipitation with monoclonal antiHSP90 antibody. Conditions for growth and immunoprecipitation are given in "Materials and methods" section. HSP90 immunoprecipitates from the three species were resolved by 2-DGE gels following image analysis. Numbered spots marked with circles corresponded to common proteins identified by MALDI-TOF MS and described in Tables 1, 2, and 3. The figure is a representative of four 2-DGE experiments of $S$. oneidensis (red circles; a), S. frigidimarina (green circles; b), and $P$. frigidicola (blue circles; c)

confirm this, we attempted to identify most of the HSP90 coimmunoprecipitated proteins in silver-stained 2-DGE gels from $S$. oneidensis, but those proteins related to energy metabolism and protein synthesis that had been found in psychrophilic species did not co-immunoprecipitate with HSP90 in S. oneidensis (Table 1). Following identification, spot migration in the 2-DGE gels was reexamined and the following discrepancies were noted. Spots 10, 13, 14, 27, and 28; four ribosomal proteins, L1, S4, S5, and S3; and hypothetical protein Pcryo_1853 focused at a lower $\mathrm{p} I$ in the 2-DGE gels (Fig. 5); three proteins had molecular weights inconsistent with their predicted molecular weight; spot 16 migrated more slowly (was larger) than expected for Rne in S. frigidimarina while spots 17 and 19 in P. frigidicola migrated more quickly (were smaller) than expected for RNApol and PolyA, respectively. These differences in mass and $\mathrm{p} I$ may be due to posttranslational modifications, truncated or degraded forms, aberrant migration, and/or errors in determining masses from the gels. In addition, errors in genome annotation can result in mismatches between predicted and observed molecular weight.

Interaction of DnaK and GroEL with HSP90 To demonstrate that client proteins really interact physically with HSP90, we investigated the effect of the specific inhibitor 17AGG on HSP90 complexes. The addition of the inhibitor to HSP90 immunoprecipitates resulted in the loss of several proteins in HSP90 complexes. In these complexes, the loss of DnaK and GroEL was very evident when they were detected by 2-DGE in HSP90 immunoprecipitates incubated with 17AGG (Fig. 7a).

The interaction between DnaK or GroEL and HSP90 was also confirmed by Western blot analysis with antiDnaK or anti-GroEL antibodies in HSP90 immunoprecipitates (Fig. 7b) and by Western blot analysis with antiHSP90 antibodies in DnaK or GroEL immunoprecipitates (Fig. 7c).

Global HSP90 interaction network The global HSP90 interaction network deduced from the experimental data obtained from the study of $S$. oneidensis, $S$. frigidimarina, and $P$. frigidicola is represented in Fig. 8. It shows the proteins associated with HSP90 in each bacterial species; a color code differentiates their cellular function. 
Table 1 Identification of HSP90-interacting proteins in S. oneidensis

Identified in S. oneidensis

\begin{tabular}{|c|c|c|c|c|c|c|}
\hline $\begin{array}{l}\text { Spot } \\
\text { number }\end{array}$ & $\begin{array}{l}\text { Theoretical/apparent } \\
M_{\mathrm{w}}(\mathrm{kDa})\end{array}$ & $\begin{array}{l}\text { Theoretical/ } \\
\text { apparent } \mathrm{p} I\end{array}$ & $\begin{array}{l}\text { Name/accession } \\
\text { number }\end{array}$ & $\begin{array}{l}\text { Protein } \\
\text { score }^{a}\end{array}$ & $\begin{array}{l}\text { Common in } S . \text { oneidensis } \\
\text { and } S . \text { frigidimarina }\end{array}$ & $\begin{array}{l}\text { Common in } S \text {. oneidensis } \\
\text { and } P \text {. frigidicola }\end{array}$ \\
\hline 1 & $155 / 150$ & $5.6 / 4.5$ & PK/NP_717078 & 66 & + & \\
\hline 2 & $69 / 70$ & $4.8 / 4.9$ & DnaK/NP_716751 & 137 & + & + \\
\hline 3 & $60 / 64$ & $6.7 / 6.7$ & FR/1D4C_A & 195 & + & \\
\hline 4 & $61 / 60$ & $4.9 / 6$ & S1/NP_717992 & 129 & + & \\
\hline 5 & $57 / 57$ & $4.8 / 5.2$ & GroEL/NP_716337 & 142 & + & + \\
\hline 6 & $42 / 42$ & $6.2 / 6.5$ & MCS/NP_715984 & 71 & + & \\
\hline 7 & $40 / 40$ & $4.7 / 5.8$ & Porin/NP_719427 & 322 & + & \\
\hline 8 & $29 / 38$ & $6.5 / 6.4$ & HypSO4719/NP_720235 & 167 & + & \\
\hline 9 & $26 / 35$ & $5.9 / 6.2$ & SSB/NP_719558 & 155 & + & \\
\hline 10 & $25 / 35$ & $9.6 / 6.5$ & L1/NP_715861 & 168 & + & \\
\hline 11 & $28 / 29$ & $5.5 / 4.5$ & HypSO3578/NP_719123 & 84 & + & \\
\hline 12 & $27 / 30$ & $8.5 / 5.3$ & HypSO2746/NP_718330 & 130 & + & \\
\hline 13 & $23 / 23$ & $10.1 / 6$ & S4/NP_715895 & 79 & + & \\
\hline 14 & $18 / 18$ & $10.1 / 5$ & S5/YP_961580 & 131 & + & \\
\hline 15 & $16 / 12$ & $5.3 / 4.2$ & Usp/NP_719222 & 107 & + & \\
\hline 90 & $72 / 72$ & $5.3 / 5.3$ & HTPG/NP_717622 & 163 & + & + \\
\hline 135 & $105 / 110$ & $5.7 / 5.8$ & GDH/NP_716412 & 216 & & \\
\hline 136 & $115 / 120$ & $6.1 / 6.3$ & SRR/NP_718130 & 90 & & \\
\hline 137 & $62 / 60$ & $5.0 / 5.2$ & UCP/NP_716619 & 116 & & \\
\hline 138 & $58 / 61$ & $6.4 / 5.7$ & TR/NP_718048 & 123 & & \\
\hline 139 & $52 / 58$ & $5.2 / 5.3$ & AP/NP_719845 & 225 & & \\
\hline 140 & $50 / 47$ & $5.3 / 5.3$ & hslU/NP_719692 & 98 & & \\
\hline 141 & $44 / 42$ & $5.1 / 5.2$ & EF-T/YP_732335 & 188 & & \\
\hline 142 & $39 / 40$ & $5.2 / 5.2$ & O-FMN/NP_718946 & 189 & & \\
\hline 143 & $39 / 41$ & $5.1 / 5.2$ & HPD/NP_717569 & 205 & & \\
\hline 144 & $28 / 30$ & $5.4 / 5.9$ & HypSO3184/NP_718740 & 120 & & \\
\hline 145 & $22 / 23$ & $5.0 / 4.3$ & AHR/YP_734504 & 250 & & \\
\hline 146 & $17 / 15$ & $5.8 / 6.1$ & FUR/YP_869355 & 176 & & \\
\hline 147 & $29 / 20$ & $7.9 / 8.5$ & Flagellin/NP_718793 & 210 & & \\
\hline 148 & $16 / 14$ & $5.5 / 5.8$ & NDK/NP_717870 & 451 & & \\
\hline Total, 30 & & & & & 16 & 3 \\
\hline
\end{tabular}

$P K$ protein kinase, DnaK chaperone protein DnaK, $F R$ chain A, crystal structure of the uncomplexed form of the flavocytochrome C fumarate reductase, S1 30S ribosomal protein S1, GroEL chaperone protein GroEL, MCS methylcitrate synthase, Porin outer membrane porin, HypSO4719 hypothetical protein SO4719, SSB putative single-strand binding protein, L1 50S ribosomal protein L1, HypSO3578 hypothetical protein SO3578, HypSO2746 hypothetical protein SO2746, S4 30S ribosomal protein S4, S5 30S ribosomal protein S5, Usp universal stress protein, HTPG high temperature protein G, GDH glycine dehydrogenase, $S R R$ sensor histidine kinase/response regulator, $U C P$ urease domain-containing protein, $T R$ transporter, $A P$ agglutination protein, $h s l U$ ATP-dependent protease ATP-binding subunit, $E F-T$ elongation factor Tu, $O-F M N$ oxidoreductase FMN-binding, HPD 4-hydroxyphenylpyruvate dioxygenase, HypSO3184 hypothetical protein SO3184, AHR alkyl hydroperoxide reductase/thiol specific antioxidant/mal allergen, FUR ferric uptake regulator, $N D K$ nucleoside diphosphate kinase

${ }^{a}$ Protein scores greater than 66 were significant $(p<0.05)$ in the Mascot database search algorithm (Matrix Science, UK)

\section{Discussion}

As the induction of HSPs is a universal response and HSP90-interacting proteins have been described to participate in critical cell functions (Chen et al. 2006), we have investigated HSP90 and HSP90-associated proteins to elucidate their participation in bacterial viability and cold adaptation. Although most of previous studies in other bacterial species had been carried out with $h t p G$ mutants (Bardwell and Craig 1988; Hossain and Nakamoto 2002; Tanaka and Nakamoto 1999; Versteeg et al. 1999), we have chosen a different strategy using the specific HSP90 
Table 2 Identification of HSP90-interacting proteins in S. frigidimarina

Identified in S. frigidimarina

\begin{tabular}{|c|c|c|c|c|c|c|}
\hline $\begin{array}{l}\text { Spot } \\
\text { number }\end{array}$ & $\begin{array}{l}\text { Theoretical/apparent } \\
M_{\mathrm{w}}(\mathrm{kDa})\end{array}$ & $\begin{array}{l}\text { Theoretical/ } \\
\text { apparent } \mathrm{p} I\end{array}$ & $\begin{array}{l}\text { Name/accession } \\
\text { number }\end{array}$ & $\begin{array}{l}\text { Protein } \\
\text { score }^{\mathrm{a}}\end{array}$ & $\begin{array}{l}\text { Common in } S \text {. frigidimarina } \\
\text { and } S . \text { oneidensis }\end{array}$ & $\begin{array}{l}\text { Common in } S \text {. frigidimarina } \\
\text { and } P \text {. frigidicola }\end{array}$ \\
\hline 1 & $150 / 150$ & $5.3 / 4.5$ & PK/YP_752088 & 100 & + & \\
\hline 2 & $69 / 70$ & $4.7 / 4.9$ & DnaK/YP_749660 & 72 & + & + \\
\hline 3 & $63 / 65$ & $6.3 / 6.7$ & FR/YP_752356 & 83 & + & \\
\hline 4 & $61 / 60$ & $4.9 / 6$ & S1/YP_750807 & 78 & + & \\
\hline 5 & $57 / 57$ & $4.8 / 5.3$ & GroEL/YP_752326 & 125 & + & + \\
\hline 6 & $41 / 42$ & $6.1 / 6.5$ & MCS/YP_750544 & 171 & + & \\
\hline 7 & $40 / 40$ & $4.7 / 5.8$ & Porin/YP_749202 & 178 & + & \\
\hline 8 & $30 / 38$ & $8.3 / 6.4$ & STS/YP_752581 & 125 & + & \\
\hline 9 & $26 / 35$ & $5.9 / 6.2$ & SSB/YP_752376 & 99 & + & \\
\hline 10 & $25 / 35$ & $9.3 / 6.5$ & L1/YP_748839 & 89 & + & \\
\hline 11 & $26 / 29$ & $5.6 / 4.5$ & HypSfri0668/YP_749366 & 82 & + & \\
\hline 12 & $27 / 30$ & $6.4 / 5.3$ & HypSfri1464/YP_750154 & 93 & + & \\
\hline 13 & $25 / 23$ & $9.4 / 6$ & S4/YP_748839 & 62 & + & \\
\hline 14 & $18 / 20$ & $10.1 / 5$ & S5/YP_748866 & 110 & + & \\
\hline 15 & $16 / 12$ & $5.3 / 4.2$ & Usp/YP_749629 & 91 & + & \\
\hline 16 & $145 / 160$ & $5.6 / 4.7$ & Rne/YP_734533 & 86 & & + \\
\hline 17 & $156 / 110$ & $5.9 / 5.6$ & RNApol/YP_732331 & 115 & & + \\
\hline 18 & $96 / 100$ & $6.0 / 5.6$ & IF2/YP_749681 & 155 & & + \\
\hline 19 & $50 / 75$ & $9.3 / 8$ & PolyA/YP_001762154 & 109 & & + \\
\hline 20 & $77 / 80$ & $5.0 / 5.6$ & EF-G/YP_748846 & 133 & & + \\
\hline 21 & $53 / 65$ & $5.3 / 6$ & NADsyn/YP_752467 & 97 & & + \\
\hline 22 & $59 / 60$ & $5.5 / 5.3$ & ICL/YP_751815 & 150 & & + \\
\hline 23 & $35 / 40$ & $5.1 / 5.3$ & MDH/YP_751848 & 94 & & + \\
\hline 24 & $30 / 40$ & $5.2 / 6$ & $\mathrm{MinD} / \mathrm{YP} \_750424$ & 227 & & + \\
\hline 25 & $41 / 39$ & $5.4 / 5.4$ & SCoA/YP_751025 & 95 & & + \\
\hline 26 & $40 / 38$ & $5.2 / 6.2$ & ADH/YP_752100 & 134 & & + \\
\hline 27 & $26 / 30$ & $10.0 / 6.3$ & $\mathrm{~S} 3 / \mathrm{YP} \_748855$ & 152 & & + \\
\hline 28 & $20 / 25$ & $4.6 / 6$ & Pcryo/YP_749290 & 192 & & + \\
\hline 29 & $30 / 24$ & $5.0 / 4.9$ & TerD/ABI70595 & 134 & & + \\
\hline 30 & $23 / 20$ & $9.9 / 8.6$ & L3/YP_748849 & 142 & & + \\
\hline 31 & $20 / 20$ & $8.5 / 6.3$ & IF3/YP_001366423 & 129 & & + \\
\hline 32 & $28 / 18$ & $4.8 / 5.3$ & LysM/YP_738353 & 189 & & + \\
\hline 33 & $14 / 18$ & $11.0 / 10$ & S11/YP_748872 & 157 & & + \\
\hline 34 & $10 / 17$ & $11.0 / 10$ & L27/YP_751764 & 128 & & + \\
\hline 90 & $72 / 72$ & $5.1 / 5.3$ & HTPG/YP_750227 & 109 & + & + \\
\hline Total, 35 & & & & & 16 & 22 \\
\hline
\end{tabular}

$P K$ protein kinase, DnaK chaperone protein DnaK, FR chain A, crystal structure of the uncomplexed form of the flavocytochrome C fumarate reductase, S1 30S ribosomal protein S1, GroEL chaperone protein GroEL, MCS methylcitrate synthase, Porin outer membrane porin, STS putative sulfate transport system substrate-binding protein, SSB putative single-strand binding protein, L1 50S ribosomal protein L1, HypSfri0668 hypothetical protein Sfri0668, HypSfri1464 hypothetical protein Sfri1464, S4 30S ribosomal protein S4, S5 30S ribosomal protein S5, Usp universal stress protein, Rne ribonuclease, Rne/Rng family, RNApol DNA-directed RNA polymerase, subunit beta-prime, $I F 2$ translation initiation factor IF2, polyA poly (A) polymerase, $E F-G$ elongation factor G, $N A D s y n$ NAD (+) synthase (glutamine-hydrolyzing), ICL isocitrate lyase and phosphorylmutase, $M D H$ malate dehydrogenase, MinD septum site-determining MinD, SCoA succinyl-CoA synthetase, $A D H$ alcohol dehydrogenase GroES-like protein, S3 ribosomal protein S3, Pcryo hypothetical protein Pcryo_1853, TerD probable tellurium resistance TerD, L3 ribosomal protein L3, IF3 translation initiation factor IF3, LysM peptidoglycan-binding LysM, S11 30S ribosomal protein S11, L27 50S ribosomal protein $\mathrm{L} 27, H T P G$ high temperature protein $\mathrm{G}$

${ }^{a}$ Protein scores greater than 62 were significant $(p<0.05)$ in the Mascot database search algorithm (Matrix Science, UK) 
A

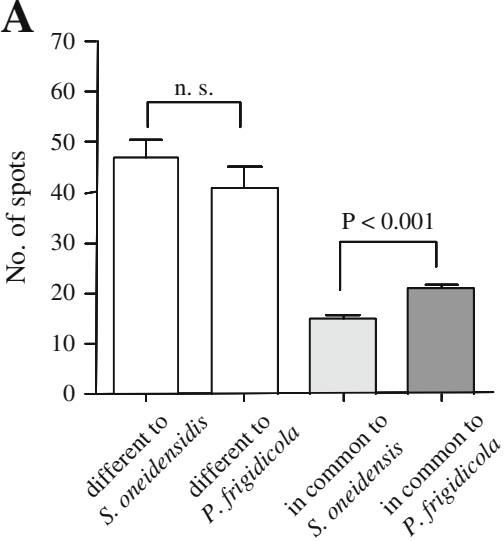

B

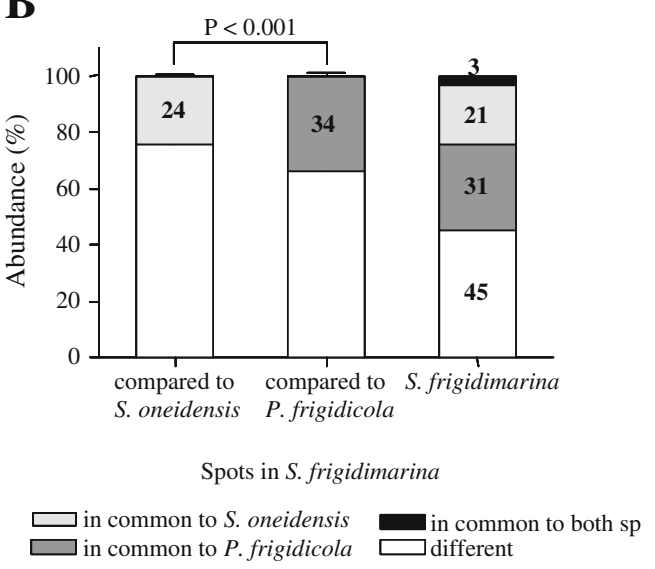

Fig. 6 Distribution of HSP90-interacting proteins. The relative protein abundance of HSP90-associated proteins detected in 2-DGE gels was compared between $S$. frigidimarina and either $S$. oneidensis or $P$. frigidicola, considering the common or different number of spots in number (a) and in percentage (b). In $\mathbf{b}$, the total percentages of spots in $S$. frigidimarina are also represented. Statistical differences were compared by Student's $t$ test (n.s. not significant)

inhibitor 17AGG, as the amino-terminal domain of approximately 200 amino acid residues which contains the geldanamycin/nucleotide binding site (Prodromou et al. 1997; Stebbins et al. 1997) is conserved in Shewanella. The relative growing of $S$. oneidensis and S. frigidimarina in the presence of 17AGG indicates that HTPG is not completely essential for normal growth, as previously observed for $E$. coli (Bardwell and Craig 1988) and B. subtilis (Versteeg et al. 1999) in thermal stress, but this protein plays an important role especially in cold acclimation, according with the significant differences obtained in cultures of $S$. frigidimarina at $12^{\circ} \mathrm{C}$ compared to its control $(P<0.001$; Fig. 1). This interesting role of HSP90 could be an effect of its interaction with other client proteins, which might be determined by temperature.

An amino acid sequence alignment of HSP90 for comparison of bacterial species and their subsequent phylogenetic analysis was undertaken, which demonstrated that Shewanella species showed similar HSP90 sequences, with regard to both their DNA and protein sequences and a clear difference between the genus Shewanella and Psychrobacter. Nevertheless, preliminary assays to compare HSP90 co-immunoprecipitated proteins among $S$. oneidensis, S. frigidimarina, and P. frigidicola using SDS-PAGE demonstrated considerable analogy in the protein pattern between $S$. frigidimarina and $P$. frigidicola.

In order to elucidate the HSP90-associated proteins common to both psychrophilic bacteria, we analyzed HSP90 immunoprecipitates performed with specific antibodies using a widely tested methodology (Cid et al. 2004, 2007a). In our studies, we used an anti-HSP90 monoclonal antibody that was raised against a conserved epitope shown to react with HSP90 in multiple species, including the prokaryote HSP90 homolog HTPG (Lopatin et al. 2000; Riehl et al. 1985). The antibody also recognized the protein in the bacterial species studied, as was demonstrated by Western blot and MALDI-TOF MS analysis.

Several 1-DGE experiments using immunoprecipitated samples confirmed that HSP90 complexes from psychrophilic species had in common more proteins than had species from the same genus. We endeavored to compare these three species which represent either the same genus or the same environment. An experimental approach using 2DGE demonstrated that the number of common proteins in HSP90 complexes in both psychrophilic bacteria is very significantly higher than the number of common proteins associated to HSP90 in Shewanella species, although they are closely related phylogenetically. Thus, using MALDITOF MS, we systematically identified those proteins that interact in vivo with HSP90 and are key determinants of protein functions at different temperatures (Strocchi et al. 2006). Proteins that interact only very transiently with HSP90 may have escaped detection in this analysis, but such proteins are not expected to be strongly dependent on the chaperone complexes for their function. Further, 2-DGE comparisons were performed between the whole extracts and their corresponding immunoprecipitates to check that the identified proteins were enriched in the precipitates.

All HSP90 interactions detected in the three bacterial species are summarized in Fig. 8. Based on our results, we have classified the common HSP90-associated proteins in the three bacterial species according to the categories below.

Chaperones These are involved in protein folding which is an essential step to ensure functional assembly. When the temperature falls, these proteins act mainly on the regulation of cellular protein synthesis, particularly at the level of initiation of translation and also prevent the formation of mRNA secondary structures (Georlette et al. 2004). We have found two main chaperones associated with HSP90 in the three species: DnaK and GroEL. The chaperone DnaK 
Table 3 Identification of HSP90-interacting proteins in P. frigidicola

Identified in P. frigidicola

\begin{tabular}{|c|c|c|c|c|c|c|}
\hline $\begin{array}{l}\text { Spot } \\
\text { number }\end{array}$ & $\begin{array}{l}\text { Theoretical/apparent } \\
M_{\mathrm{w}}(\mathrm{kDa})\end{array}$ & $\begin{array}{l}\text { Theoretical/ } \\
\text { apparent } \mathrm{p} I\end{array}$ & $\begin{array}{l}\text { Name/accession } \\
\text { number }\end{array}$ & $\begin{array}{l}\text { Protein } \\
\text { score }^{\mathrm{a}}\end{array}$ & $\begin{array}{l}\text { Common in } P . \text { frigidicola } \\
\text { and } S \text {. oneidensis }\end{array}$ & $\begin{array}{l}\text { Common in } P \text {. frigidicolo } \\
\text { and } S \text {. frigidimarina }\end{array}$ \\
\hline 2 & $70 / 70$ & $4.5 / 4.9$ & DnaK/AAZ19979 & 135 & + & + \\
\hline 5 & $58 / 59$ & $4.8 / 5.2$ & GroEL/Q4FU94 & 103 & + & + \\
\hline 16 & $160 / 160$ & $5.4 / 4.7$ & Rne/YP_579550 & 178 & & + \\
\hline 17 & $155 / 110$ & $5.9 / 5.6$ & RNApol/Q1Q8Q0 & 150 & & + \\
\hline 18 & $100 / 100$ & $6.0 / 5.5$ & IF2/YP_263377 & 105 & & + \\
\hline 19 & $84 / 75$ & $9.6 / 8$ & PolyA/YP_579391 & 145 & & + \\
\hline 20 & $79 / 80$ & $4.9 / 5.6$ & EF-G/YP_265177 & 119 & & + \\
\hline 21 & $61 / 65$ & $5.3 / 6$ & NADsyn/YP_001280772 & 120 & & + \\
\hline 22 & $59 / 60$ & $5.1 / 5.3$ & ICL/YP_581121 & 96 & & + \\
\hline 23 & $35 / 40$ & $4.9 / 4.9$ & MDH/YP_581305 & 157 & & + \\
\hline 24 & $30 / 40$ & $5.1 / 6$ & MinD/YP_581352 & 169 & & + \\
\hline 25 & $42 / 39$ & $4.7 / 5.3$ & SCoA/ZP_00146840 & 122 & & + \\
\hline 26 & $39 / 39$ & $5.2 / 6$ & ADH/YP_581659 & 103 & & + \\
\hline 27 & $27 / 30$ & $10.2 / 6.3$ & S3/ZP_01272929 & 173 & & + \\
\hline 28 & $25 / 25$ & $8.8 / 6$ & Pcryo/YP_581114 & 126 & & + \\
\hline 29 & $20 / 24$ & $4.4 / 4.9$ & TerD/YP_264050 & 100 & & + \\
\hline 30 & $22 / 20$ & $9.9 / 8.6$ & L3/YP_263786 & 84 & & + \\
\hline 31 & $19 / 20$ & $8.5 / 6.3$ & IF3/YP_265380 & 184 & & + \\
\hline 32 & $18 / 18$ & $5.9 / 5.8$ & LysM/YP_579785 & 73 & & + \\
\hline 33 & $14 / 18$ & $11.0 / 10$ & S11/YP_263809 & 116 & & + \\
\hline 34 & $9 / 17$ & $10.7 / 10$ & L27/YP_264854 & 109 & & + \\
\hline 90 & $74 / 74$ & $4.7 / 5.2$ & HTPG/YP_581259 & 106 & + & + \\
\hline 335 & $51 / 50$ & $4.5 / 5.9$ & TF/YP_581494 & 112 & & \\
\hline 336 & $33 / 33$ & $5.3 / 5.0$ & UP/YP_264782 & 86 & & \\
\hline 337 & $35 / 35$ & $6.1 / 6.8$ & UP/YP_580621 & 126 & & \\
\hline 338 & $28 / 28$ & $5.3 / 5.3$ & TRR/YP_001279607 & 83 & & \\
\hline 339 & $31 / 29$ & $5.3 / 5.6$ & EDR/YP_001280155 & 79 & & \\
\hline 340 & $24 / 27$ & $5.2 / 4.9$ & AK/YP_001279708 & 72 & & \\
\hline 341 & $23 / 26$ & $8.6 / 7.1$ & RMTE/YP_001279439 & 117 & & \\
\hline 342 & $23 / 24$ & $9.5 / 9.7$ & DsbA/YP_579397 & 89 & & \\
\hline Total, 30 & & & & & 3 & 22 \\
\hline
\end{tabular}

DnaK chaperone protein DnaK, GroEL chaperone protein GroEL, Rne ribonuclease, Rne/Rng family, RNApol DNA-directed RNA polymerase, subunit beta-prime, IF2 translation initiation factor IF2, polyA poly (A) polymerase, $E F-G$ elongation factor G, NADsyn NAD (+) synthase (glutamine-hydrolyzing), ICL isocitrate lyase and phosphorylmutase, $M D H$ malate dehydrogenase, MinD septum-site determining MinD, SCoA succinyl-CoA synthetase, $A D H$ alcohol dehydrogenase GroES-like protein, S3 ribosomal protein S3, Pcryo hypothetical protein Pcryo_1853, TerD probable tellurium resistance TerD, L3 ribosomal protein L3, IF3 translation initiation factor IF3, LysM peptidoglycan-binding LysM, S11 30 S ribosomal protein S11, L27 50S ribosomal protein L27, HTPG high temperature protein $\mathrm{G}, T F$ trigger factor, UP uncharacterized protein, $T R R$ two-component response regulator, EDR exodeoxyribonuclease III, $A K$ adenylate kinase, RMTE ribosomal RNA large subunit methyltransferase E, $D s b A$ oxidoreductase DSBA

${ }^{a}$ Protein scores greater than 72 were significant $(p<0.05)$ in the Mascot database search algorithm (Matrix Science, UK)

(HSP70) has been found as a HSP90-interacting protein in the three species, which probably takes part in the mechanisms of stress tolerance through the DnaK/DnaJ system. It has also been demonstrated in other psychrophilic bacteria such as Colwellia maris that the dnaK gene is highly expressed on incubation of the cells at $18-20^{\circ} \mathrm{C}$
(Yamauchi et al. 2004). The chaperone GroEL (HSP60) is essential for growth and viability under many environmental conditions (Fayet et al. 1989; Houry et al. 1999). In vivo, GroEL is involved in the folding of approximately $10 \%$ of newly synthesized polypeptides (Wong and Houry 2004). Several studies have demonstrated the catalytic 
A

S. oneidensis

DnaK

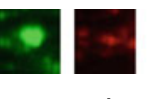

$-\quad+$

S. frigidimarina

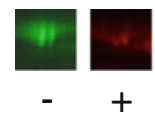

P. frigidicola

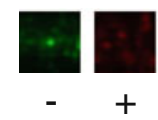

GroEL

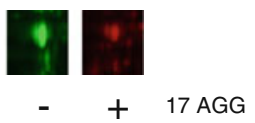

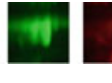

$-\quad+17 \mathrm{AGG}$

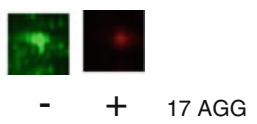

B

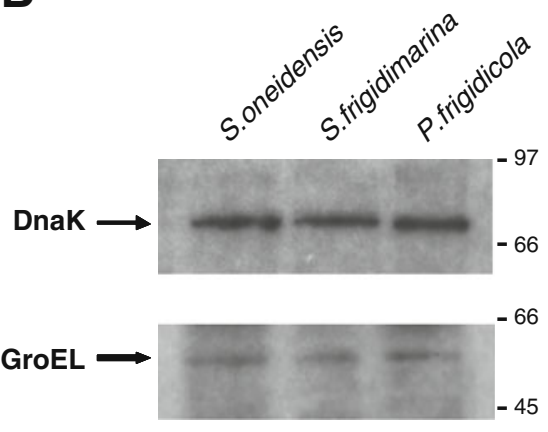

C

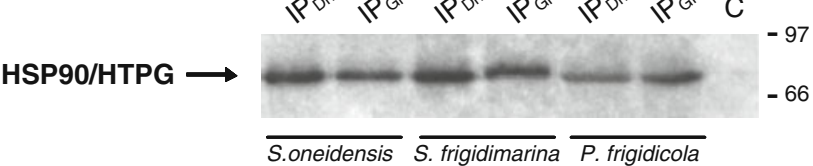

Fig. 7 Interaction of DnaK and GroEL with HSP90. a Effect of the specific HSP90 inhibitor 17AGG. HSP90 immunoprecipitates were incubated without (-) and with (+) 17AGG and after labeled with Cy3 (control, in green) and Cy5 (in red), respectively. The immunoprecipitates were combined and analyzed by 2-DGE as in Fig. 5. Gels were scanned with a Typhoon Imager. The codetected spots corresponding to DnaK and GroEL in $S$. oneidensis, $S$. frigidimarina, and $P$. frigidicola are represented. Similar results were obtained in three separated experiments. b Western blot analysis with anti-DnaK antibodies (top) or anti-GroEL antibodies (bottom) of HSP90 immunoprecipitates. c Western blot analysis with anti-HSP90 in DnaK and GroEL immunoprecipitates. Line $C$ control of unspecific binding to the beads. $M W$ are indicated. The figure is a representative of three different experiments

\section{Adaptation to cold environment}

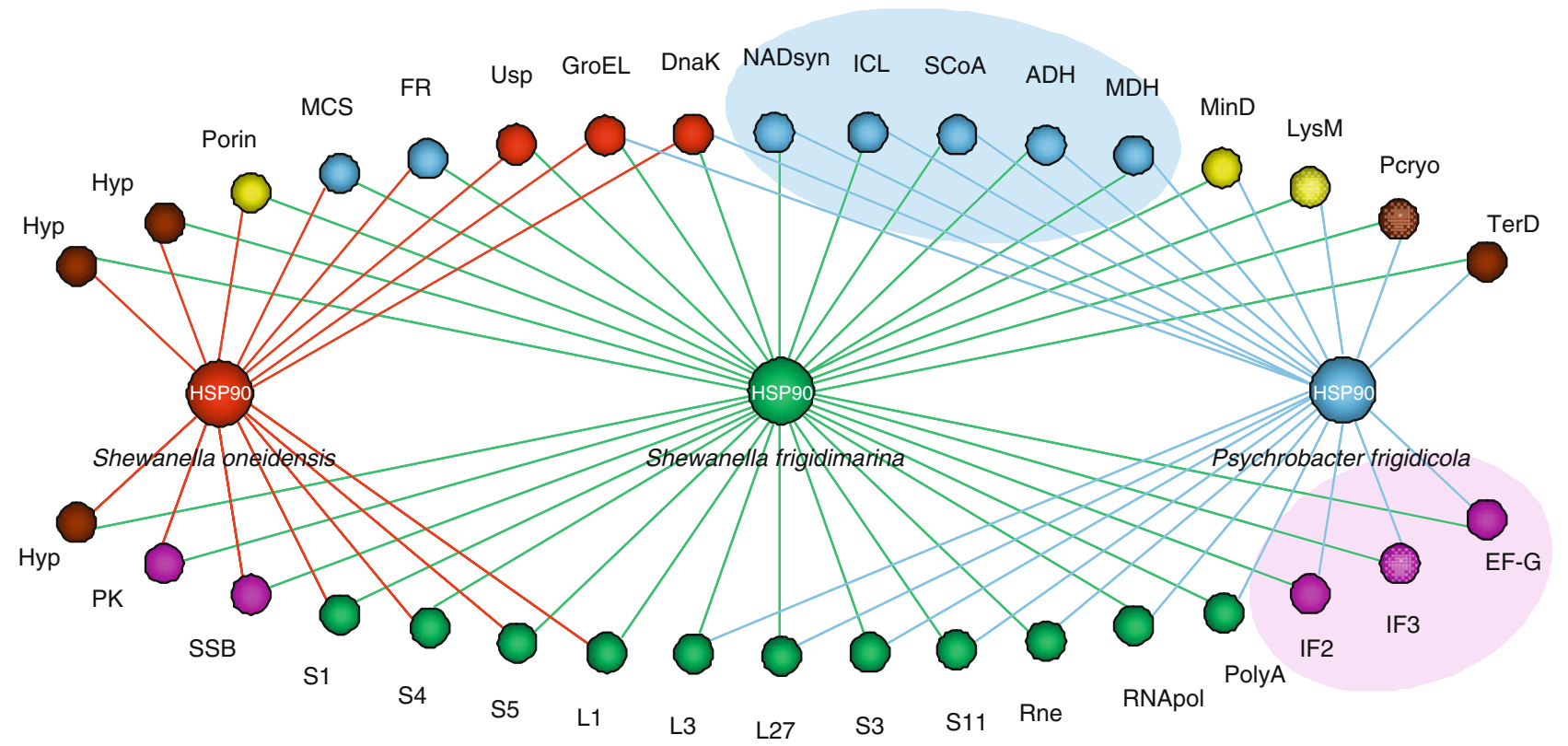

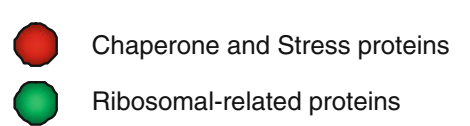

Fig. 8 Overview of the HSP90 interaction data. Network overview showing the proteins that interact with HSP90 in S. oneidensis, $S$. frigidimarina, and $P$. frigidicola. HSP90-interacting proteins are colored according to cellular processes. Shaded circles around groups of proteins indicate the main groups of HSP90-interacting proteins found in psycrophilic bacteria: proteins related to energy metabolism (shaded in blue) and protein synthesis (shaded in pink) 
activity of GroEL in the folding process of soluble proteins such as malate dehydrogenase and enolase (Goulhen et al. 2004; Houry et al. 1999).

Plasma membrane and cell wall It has been reported that adaptation to the cold reduces membrane fluidity. Some proteins associated with membrane and cell wall formation have been found to co-immunoprecipitate with HSP90 in our experiments; of these, outer membrane porin appeared in Shewanella. This porin forms hydrophilic channels through the outer membrane, and it has been reported that GroEL is able to refold a disordered porin and promote the recovery of its pore-forming activity (Goulhen et al. 2004). In psychrophiles, septum site-determining MinD and peptidoglycan-binding LysM were found. It has already been demonstrated in other psychrophilic species that inhibition of septum formation is temperature dependent (Gounot et al. 1977). In S. frigidimarina and P. frigidicola, the septum site-determining MinD has been found to bind to HSP90, also indicating a possible temperature-dependent mechanism in septum formation.

Replication and protein synthesis It has been documented that the ability of psychrophiles to grow at low temperatures depends on adaptative changes in cellular proteins and lipids (Russell 1990). Changes in proteins are genotypic and are related to the properties of enzymes and translation systems, whereas changes in lipids are phenotypic and are important in regulating membrane fluidity and permeability. In our study, we have found some translation factors associated with HSP90 in psychrophilic species but not in S. oneidensis, such as translation initiation factor IF2, translation initiation factor IF3, and elongation factor G. It has been assessed that one of the major effects of cold temperatures on microorganisms is the inhibition of translation initiation and elongation (Broeze et al. 1978; Georlette et al. 2004). In these psychrophilic species, the association of HSP90 with these translation factors may represent a method of coping with the stress situation of cold temperatures. As a similar example, in E. coli, it has been demonstrated that expression of IF2 and IF3 is enhanced after cold shock that contributes to establishing the cold shock translational bias whereby cold shock mRNAs are preferentially translated by cold stressed cells while bulk mRNAs are discriminated against (Giuliodori et al. 2004, 2007).

Ribosomal-related proteins Ribosomal proteins L1, S1, S4, and S5 were detected in Shewanella complexes, while other four ribosomal proteins, S3, S11, L3, and L27, were only present in complexes from psychrophilic species. Among proteins related to RNA, three proteins have been found in psychrophiles: ribonuclease, Rne/Rng family, poly (A) polymerase, and DNA-directed RNA polymerase, subunit beta-prime.

Energy metabolism For organisms inhabiting environments at extreme temperatures, energy levels must be adjusted accordingly in order to maintain biological processes at viable levels. It has been demonstrated that in the psychrophiles, adenylate levels are invariably elevate as temperatures fall (Napolitano and Shain 2005). The stoichiometry of these changes target pivotal enzymes in cellular metabolism, and there is also evidence for compensation of enzymatic activity in some energyrelated pathways (Napolitano and Shain 2005). Among the enzymes involved in carbohydrate metabolism, we have found isocitrate lyase and phosphorylmutase, succinyl-CoA synthetase, alcohol dehydrogenase, NAD (+) synthase, and malate dehydrogenase associated with HSP90 in both psychrophilic species, but not in $S$. oneidensis. A few crystallographic structures of cold-adapted enzymes have been elucidated. The analysis of their 3D structure, taking malate dehydrogenase as an example, revealed that better accessibility of the catalytic cavity to ligands and a decrease in conformational stability together with an increase in the flexibility of the molecular structure (Georlette et al. 2004)
Fig. 9 HSP90-interacting protein cluster. Cluster analysis resolved with the common proteins identified by MALDITOF MS (see Tables 1, 2, and 3) in HSP90 immunoprecipitates from $S$. oneidensis, $S$. frigidimarina, and $P$. frigidicola comparing these bacterial species and showing the relationship between both psychrophilic species

\section{HSP90-interacting proteins}

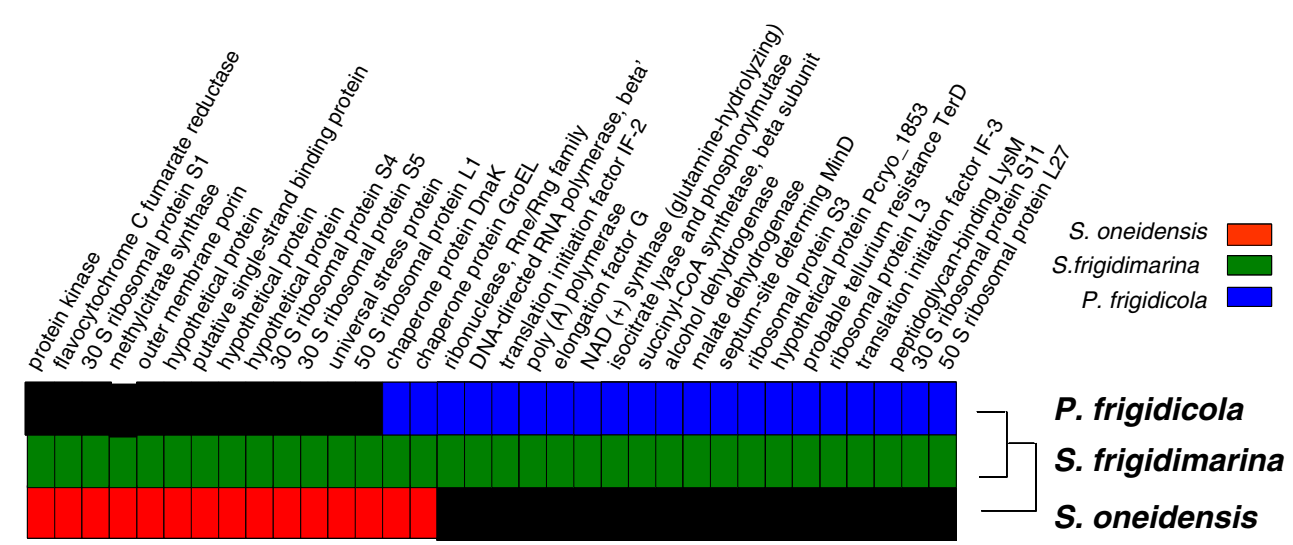


can be achieved by chaperone intervention. Flavocytochrome reductase and methylcitrate synthase are the only proteins in this group that are common to both Shewanella species but are not present in P. frigidicola.

Others Several hypothetical proteins have been found associated to HSP90: Hypothetical proteins SO4719, SO3578, and SO2746 in S. oneidensis were found to be similar in BLAST analysis to three hypothetical proteins in S. frigidimarina. Further, hypothetical protein Pcryo_1853 and probable tellurium resistance TerD were located in psychrophiles.

In our study, HSP90 sequence comparisons have differentiated Shewanella and Psychrobacter as two different genera. Nevertheless, regarding the HSP90associated proteins, a new cluster can be hypothesized (Fig. 9), which suggests that the general similarity of HSP90 interactors in psychrophilic bacteria implies that the same selective mechanisms must occur in both coldadapted species.

In conclusion, although general mechanisms of adaptation to cold environments are well-known in bacteria, they have traditionally been studied in cold shock experiments (Polissi et al. 2003), but not in long-term adaptation. From our results, it seems that in the genus Shewanella, this adaptation is achieved through a chaperone system that involves DnaK and GroEL proteins, but in psychrophilic bacteria, other proteins-i.e., proteins associated to HSP90 - with main functions such as energy metabolism and protein synthesis may contribute to the mechanism of adaptation to cold environments. This hypothesis leads to the contention that complex stress response networks should not only be determined by transcriptome or proteome analysis alone since they are also modulated by the environment of the bacteria. The protein interactions and assemblies that we have identified provide the first experimental study considering environmental influences with regard to protein interaction networks that should be taken into account in "systems biology" approaches and in computational interaction predictions and agree with some published theoretical works (Babu et al. 2006).

Acknowledgments We are indebted to Drs. M. Martinez-Gomariz and C. Gil from Proteomic Unit of the Parque Científico de Madrid and to E. Camafeita from Centro Nacional de Investigaciones Cardiovasculares, Madrid. This research was supported by grants CTM/2008-00304/ANT from the Spanish Ministerio Ciencia e Innovación and grants to the Centro de Astrobiología at the Instituto National de Técnica Aeroespacial.

Open Access This article is distributed under the terms of the Creative Commons Attribution Noncommercial License which permits any noncommercial use, distribution, and reproduction in any medium, provided the original author(s) and source are credited.

\section{References}

Abate G, Aseffa A, Selassie A, Goshu S, Fekade B, WoldeMeskal D, Miörner H (2004) Direct colorimetric assay for rapid detection of rifampicin-resistant Mycobacterium tuberculosis. J Clin Microbiol 42:871-873. doi:10.1128/JCM.42.2.871-873.2004

Babu MM, Teichmann SA, Aravind L (2006) Evolutionary dynamics of prokaryotic transcriptional regulatory networks. J Mol Biol 358:614-633. doi:10.1016/j.jmb.2006.02.019

Bardwell JC, Craig EA (1988) Ancient heat shock gene is dispensable. J Bacteriol 170:2977-2983

Bowman JP, Cavanagh J, Austin JJ, Sanderson K (1996) Nobel Psychrobacter species from Antarctic ornithogenic soils. Int $\mathrm{J}$ Syst Bacteriol 46:841-848

Bowman JP, McCammon SA, Brown MV, Nichols DS, McMeekin TA (1997) Diversity and association of psychrophilic bacteria in Antarctic sea ice. Appl Environ Microbiol 63:3068-3078

Bowman JP, McCammon SA, Gibson JA, Robertson L, Nichols PD (2003) Prokaryotic metabolic activity and community structure in Antarctic continental shelf sediments. Appl Environ Microbiol 69:2448-2462. doi:10.1128/AEM.69.5.2448-2462.2003

Bozal N, Montes MJ, Tudela E, Jimenez F, Guinea J (2002) Shewanella frigidimarina and Shewanella livingstonensis sp. nov. isolated from Antarctic coastal areas. Int J Syst Evol Microbiol 52:195-205

Brinkmeyer R, Knittel K, Jurgens J, Weyland H, Amann R, Helmke E (2003) Diversity and structure of bacterial communities in Arctic versus Antarctic pack ice. Appl Environ Microbiol 9:6610-6619. doi:10.1128/AEM.69.11.6610-6619.2003

Broeze RJ, Solomon CJ, Pope DH (1978) Effects of low temperature on in vivo and in vitro protein synthesis in Escherichia coli and Pseudomonas fluorescens. J Bacteriol 134:861-874

Chen B, Zhong D, Monteiro A (2006) Comparative genomics and evolution of the HSP90 family of genes across all kingdoms of organisms. BMC Genomics 7:156. doi:10.1186/1471-2164-7-156

Cid C, Alvarez-Cermeno JC, Camafeita E, Salinas M, Alcazar A (2004) Antibodies reactive to heat shock protein 90 induce oligodendrocyte precursor cell death in culture. Implications for demyelination in multiple sclerosis. FASEB $\mathrm{J}$ 18:409-411. doi:10.1096/fj.03-0606fje

Cid C, Garcia-Villanueva M, Salinas M, Alcazar A (2007a) Detection of anti-heat shock protein 90 beta (Hsp90beta) antibodies in cerebrospinal fluid. J Immunol Methods 318:153-157. doi:10.1016/j.jim.2006.09.017

Cid C, Garcia-Bonilla L, Camafeita E, Burda J, Salinas M, Alcazar A (2007b) Proteomic characterization of protein phosphatase one complexes in ischemia-reperfusion and ischemic tolerance. Proteomics 7:3207-3218. doi:10.1002/pmic.200700214

Cid C, Garcia-Descalzo L, Casado-Lafuente V, Amils R, Aguilera A (2010) Proteomic analysis of the response of an acidophilic strain of Chlamydomonas sp. (Chlorophyta) to natural metal-rich water. Proteomics 10:1-11. doi:10.1002/pmic.200900592

Deppe U, Richnow HH, Michaelis W, Antranikian G (2005) Degradation of crude oil by an arctic microbial consortium. Extremophiles 9:461-470. doi:10.1007/s00792-005-0463-2

Fayet O, Ziegelhoffer T, Georgopoulos C (1989) The groES and groEL heat shock gene products of Escherichia coli are essential for bacterial growth at all temperatures. J Bacteriol 171:13791385

Georlette D, Blaise V, Collins T, D'Amico S, Gratia E, Hoyoux A, Marx JC, Sonan G, Feller G, Gerday C (2004) Some like it cold: biocatalysis at low temperatures. FEMS Microbiol Rev 28:25-42

Giuliodori AM, Brandi A, Gualerzi CO, Pon CL (2004) Preferential translation of cold-shock mRNAs during cold adaptation. RNA 10:265-276. doi:10.1261/rna.5164904 
Giuliodori AM, Brandi A, Giangrossi M, Gualerzi CO, Pon CL (2007) Cold-stress-induced de novo expression of infC and role of IF3 in cold-shock translational bias. RNA 13:1355-1365. doi:10. 1261/rna.455607

Goulhen F, De E, Pages JM, Bolla JM (2004) Functional refolding of the Campylobacter jejuni MOMP (major outer membrane protein) porin by GroEL from the same species. Biochem J 378:851-856. doi:10.1042/BJ20031239

Gounot AM, Novitsky TJ, Kushner DJ (1977) Effects of temperature on the macromolecular composition and find structure of psychrophilic Arthrobacter species. Can J Microbiol 23:357-362

Hartl FU, Hayer-Hartl M (2002) Molecular chaperones in the cytosol: from nascent chain to folded protein. Science 295:1852-1858. doi:10.1126/science.1068408

Heidelberg JF, Paulsen IT, Nelson KE, Gaidos EJ, Nelson WC, Read TD, Eisen JA, Seshadri R, Ward N, Methe B, Clayton RA, Meyer T, Tsapin A, Scott J, Beanan M, Brinkac L, Daugherty S, DeBoy RT, Dodson RJ, Durkin AS, Haft DH, Kolonay JF, Madupu R, Peterson JD, Umayam LA, White O, Wolf AM, Vamathevan J, Weidman J, Impraim M, Lee K, Mueller J, Khouri H, Gill J, Utterback TR, McDonald LA, Feldblyum TV, Venter JC, Nealson KH, Fraser CM (2002) Genome sequence of the dissimilatory metal iron-reducing bacterium Shewanella oneidensis. Nat Biotechnol 20:1118-1123

Hossain MM, Nakamoto H (2002) HtpG plays a role in cold acclimation in cyanobacteria. Curr Microbiol 44:291-296. doi:10.1007/s00284-001-0005-9

Houry WA, Frishman D, Eckerskorn C, Lottspeich F, Hartl FU (1999) Identification of in vivo substrates of the chaperonin GroEL. Nature 402:147-154. doi:10.1038/45977

Jorgensen BR, Huss HH (1989) Growth and activity of Shewanella putrefaciens isolated from spoiling fish. Int J Food Microbiol 9:51-62. doi:10.1016/0168-1605(89)90037-8

Kawashima T, Amano N, Koike H, Makino S, Higuchi S, Kawashima-Ohya Y, Watanabe K, Yamazaki M, Kanehori K, Kawamoto T, Nunoshiba T, Yamamoto Y, Aramaki H, Makino K, Suzuki M (2000) Archaeal adaptation to higher temperatures revealed by genomic sequence of Thermoplasma volcanium. Proc Natl Acad Sci USA 97:14257-14262

Laksanalamai P, Robb FT (2004) Small heat shock proteins from extremophiles: a review. Extremophiles 8:1-11. doi:10.1007/ s00792-003-0362-3

Lopatin DE, Combs A, Sweier DG, Fenno JC, Dhamija S (2000) Characterization of heat-inducible expression and cloning of HtpG (Hsp90 homologue) of Porphyromonas gingivalis. Infect Immun 68:1980-1987

Lovley D, Holmes DE, Nevin KP (2004) Dissimilatory Fe (III) and Mn (IV) reduction. Adv Microb Physiol 49:219-286. doi:10.1016/S0065-2911(04)49005-5

Mrázek J, Spormann AM, Karlin S (2006) Genomic comparisons among gamma-proteobacteria. Environ Microbiol 8:273-288

Napolitano MJ, Shain DH (2005) Distinctions in adenylate metabolism among organisms inhabiting temperature extremes. Extremophiles 9:93-98. doi:10.1007/s00792-004-0424-1
Polissi A, De Laurentis W, Zangrossi S, Briani F, Longhi V, Pesole G, Deho G (2003) Changes in Escherichia coli transcriptome during acclimatization at low temperature. Res Microbiol 154:573-580. doi:10.1016/S0923-2508(03)00167-0

Prodromou C, Roe SM, O'Brien R, Ladbury JE, Piper PW, Pearl LH (1997) Identification and structural characterization of the ATP/ ADP-binding site in the Hsp90 molecular chaperone. Cell 90:6575. doi:10.1016/S0092-8674(00)80314-1

Riehl RM, Sullivan WP, Vroman BT, Bauer VJ, Pearson GR, Toft DO (1985) Immunological evidence that the nonhormone binding component of avian steroid receptors exists in a wide range of tissues and species. Biochemistry 24:6586-6591

Russell NJ (1990) Cold adaptation of microorganisms. Philos Trans R Soc Lond B Biol Sci 326:595-608. doi:10.1098/rstb.1990.0034

Rutherford SL (2003) Between genotype and phenotype: protein chaperones and evolvability. Nat Rev Genet 4:263-274. doi:10.1038/ $\operatorname{nrg} 1041$

Shewan JM (1971) The microbiology of fish and fishery products-a progress report. J Appl Bacteriol 34:299-315

Stebbins CE, Russo AA, Schneider C, Rosen N, Hartl FU, Pavletich NP (1997) Crystal structure of an Hsp90-geldanamycin complex: targeting of a protein chaperone by an antitumor agent. Cell 89:239-250. doi:10.1016/S0092-8674(00)80203-2

Strocchi M, Ferrer M, Timmis KN, Golyshin PN (2006) Low temperature-induced systems failure in Escherichia coli: insights from rescue by cold-adapted chaperones. Proteomics 6:193-206. doi:10.1002/pmic.200500031

Tamura K, Dudley J, Nei M, Kumar S (2007) MEGA4: Molecular Evolutionary Genetics Analysis (MEGA) software version 4.0. Mol Biol Evol 24:1596-1599. doi:10.1093/molbev/msm092

Tanaka N, Nakamoto H (1999) HtpG is essential for the thermal stress management in cyanobacteria. FEBS Lett 458:117-123. doi:10.1016/S0014-5793(99)01134-5

Versteeg S, Mogk A, Schumann W (1999) The Bacillus subtilis htpG gene is not involved in thermal stress management. Mol Gen Genet 261:582-588

Versteeg S, Escher A, Wende A, Wiegert T, Schumann W (2003) Regulation of the Bacillus subtilis heat shock gene htpG is under positive control. J Bacteriol 185:466-474. doi:10.1128/ JB.185.2.466-474.2003

Wong P, Houry WA (2004) Chaperone networks in bacteria: analysis of protein homeostasis in minimal cells. J Struct Biol 146:79-89. doi:10.1016/j.jsb.2003.11.006

Yamauchi S, Okuyama H, Nishiyama Y, Hayashi H (2004) Gene structure and transcriptional regulation of dnaK and dnaJ genes from a psychrophilic bacterium, Colwellia maris. Extremophiles 8:283-290. doi:10.1007/s00792-004-0387-2

Zhao R, Davey M, Hsu YC, Kaplanek P, Tong A, Parsons AB, Krogan N, Cagney G, Mai D, Greenblatt J, Boone C, Emili A, Houry WA (2005) Navigating the chaperone network: an integrative map of physical and genetic interactions mediated by the hsp 90 chaperone. Cell 120:715-727. doi:10.1016/j.cell.2004.12.024

Zuehlke A, Johnson JL (2009) Hsp90 and co-chaperones twist the functions of diverse client proteins. Biopolymers 93:211-217. doi:10.1002/bip.21292 